\title{
Cecylia Judek*
}

\author{
LUDZIE KSIĄŻKI POMORZA ZACHODNIEGO. \\ Z DZIALALNOŚCI ZACHODNIOPOMORSKIEGO OKRĘGU \\ STOWARZYSZENIA BIBLIOTEKARZY POLSKICH
}

\section{Wprowadzenie}

Zalążkiem Stowarzyszenia Bibliotekarzy Polskich, jednej z najstarszych organizacji zawodowych w Polsce, była powstała w trakcie trwania I wojny światowej Komisja Historii Książnic i Wiedzy Bibliotecznej, powołana w Warszawie w 1915 roku. Dwa lata później członkowie Komisji założyli w październiku 1917 roku Związek Bibliotekarzy Polskich, skupiający bibliotekarzy, bibliografów i miłośników książek, a pierwszym przewodniczącym Związku został Ignacy Tadeusz Baranowski, historyk, dyrektor Biblioteki Ordynacji Krasińskich. Za główne zadania ZBP uznał ochronę warunków pracy bibliotekarzy, podnoszenie wiedzy zawodowej, czuwanie nad prawidłowym rozwojem bibliotek i archiwów, ujednolicenie prac bibliotecznych i bibliograficznych, prowadzonych w bibliotekach. Po odzyskaniu przez Polskę niepodległości Związek w sposób znaczący ożywił działalność. W 1927 roku Związek, reprezentując polskich bibliotekarzy, zgłosił swój akces do tworzonej w Edynburgu Międzynarodowej Federacji Stowarzyszeń i Instytucji Bibliotekarskich (IFLA - The International Federation

* mgr Cecylia Judek, Sekretarz Naukowy Książnicy Pomorskiej, adres e-mail: c.judek@ksiaznica.szczecin.pl 
of Library Associations and Institutions), uzyskując status członka założyciela. Podczas wojny, w warunkach konspiracyjnych, bibliotekarze nie tylko starali się chronić zasoby polskich bibliotek, ale także przygotowywali założenia ustawy o bibliotekach (Dekret z dnia 17 kwietnia 1946 r. o bibliotekach i opiece nad zbiorami bibliotecznymi). Po II wojnie światowej, w 1946 roku, do Związku Bibliotekarzy Polskich dołączyli archiwiści, tworząc wspólny Związek Bibliotekarzy i Archiwistów Polskich, który działał do 1953 roku. W dniach 19-20 grudnia Krajowy Zjazd Bibliotekarzy podjął decyzję o powołaniu Stowarzyszenia Bibliotekarzy Polskich, „organizacji społecznej o charakterze fachowym i naukowym, skupiającej w swoich szeregach pracowników bibliotek oraz osoby związane zawodowo lub naukowo ze sprawami bibliotekarstwa".

Po zakończeniu wojny i przejęciu Pomorza Zachodniego przez polskie władze w 1945 roku zaczęły w szybkim tempie powstawać polskie instytucje kulturalne, w tym biblioteki. W dniu 12 lipca 1945 roku rozpoczęła pracę Biblioteka Miejska w Szczecinie. W powstających w regionie bibliotekach potrzebne były wykwalifikowane kadry, których - wskutek strat wojennych - brakowało. Nieodzowne były kursy i szkolenia. Stanisław Siadkowski, organizator i pierwszy dyrektor szczecińskiej Biblioteki Miejskiej, uznał, że można je zorganizować, korzystając z pomocy powstałego po wojnie Związku Bibliotekarzy i Archiwistów Polskich, kontynuatora przedwojennego Związku Bibliotekarzy Polskich. W dniu 26 września 1946 roku na zebraniu założycielskim powołano w Szczecinie koło ZBiAP, a jego przewodniczącym został Bolesław Tuhan-Taurogiński, kierownik Archiwum Państwowego w Szczecinie, a także delegat do Wojewódzkiej Rady Narodowej. Uczestnicy spotkania za najważniejsze zadania uznali: szkolenie zawodowe, współpracę międzybiblioteczną oraz zabiegi o przyznanie bibliotekarzom i archiwistom dodatku naukowego ${ }^{1}$. Aktywnym członkiem ZBiAP w tym okresie była m.in. Maria Salomea Wielopolska, organizatorka i kierowniczka biblioteki Akademii Handlowej w Szczecinie, utworzonej w 1946 roku jako filia Akademii Handlowej w Poznaniu.

Nowo powstałe Koło ZBiAP rozpoczęło ożywioną działalność, organizując przede wszystkim prelekcje, kursy oraz szkolenia, a także angażując się w różne inne działania bibliotek. Uznając sprawę uzyskania przez pracowników biblio-

1 Pełna listę uczestników założycielskiego spotkania podał Stanisław Siadkowski (inicjator założenia Koła ZBiAP, a od 1953 r. aktywny działacz Stowarzyszenia Bibliotekarzy Polskich) w artykule: Działalność Stowarzyszenia Bibliotekarzy Polskich w regionie szczecińskim (1946-1985), w: Bibliotekarstwo na Pomorzu Szczecińskim 1945-1985. Materiaty z konferencji, red. T. Jasińska, W. Michnal, Szczecin 1986, s. 206. 
tek uprawnień zawodowych za kwestię priorytetową, zorganizowali - za zgodą Zarządu Głównego ZBiAP - Kurs Kwalifikacyjny, obejmujący 75 godzin wykładów i trwający od 19 października 1950 roku do 15 kwietnia 1951 roku. Jednym z jego słuchaczy był dr Stanisław Telega, który zachował w swoim archiwum ${ }^{2}$ zaświadczenie z ukończenia kursu. Dzięki temu dokumentowi wiemy, że kurs, którego program zatwierdziło Ministerstwo Oświaty, obejmował następujące przedmioty: zagadnienia ideologiczne i planu 6-letniego, katalogi, rozwój i organizacja bibliotek i czytelnictwa (historia książki i bibliotek), prawo biblioteczne, informatoria, administracja bibliotek. W komisji egzaminacyjnej uczestniczyła, oprócz przedstawicieli miejscowego środowiska bibliotekarskiego, Irena Gawinkowa, delegat Zarządu Głównego ZBiAP. Doktor Stanisław Telega, wówczas wicedyrektor Wojewódzkiej Biblioteki Publicznej w Szczecinie, rok później w 1952 roku wydał nakładem Związku Bibliotekarzy i Archiwistów Polskich dwa skrypty przygotowane dla słuchaczy Korespondencyjnego Kursu Bibliotekarskiego: „Pedagogika biblioteczna” (skrypt nr 13) oraz „Współzawodnictwo pracy w bibliotekarstwie" (skrypt nr 18).

\section{Czwartki i środy bibliotekarskie}

Od początku istnienia fachowej organizacji bibliotekarskiej na Pomorzu Zachodnim niezwykle aktywna była działalność szkoleniowo-organizacyjna. Niektóre z seminariów szkoleniowych organizowane były wspólnie z okręgiem koszalińskim, m.in. w 1960 roku, kiedy trwały obchody XV-lecia bibliotek regionu. W środowisku szczecińskim popularny stał się cykl czwartkowych spotkań informacyjno-szkoleniowych z udziałem prelegentów miejscowych i przyjezdnych, które organizowane były w różnych placówkach, co - jak pisał Stanisław Siadkowski - „pozwoliło na zapoznanie się z różnymi warsztatami pracy, nawiązanie kontaktów osobistych, wysłuchanie wypowiedzi różnych, często znaczących autorytetów, zobaczenie efektów praktycznych rozwiązań, lub zastosowań"3. W latach 1960-1980 odbyło się ponad 100 spotkań, które cieszyły się dużym zainteresowaniem środowiska. W burzliwym okresie lat 80., kiedy także wewnątrz SBP dochodziło do rozliczeń, podziałów i przerzedzenia szeregów, przerwano organizację „,czwartków bibliotekarskich”.

2 Archiwum to znajduje się obecnie w zbiorach Sekcji Rękopisów Działu Zbiorów Specjalnych Książnicy Pomorskiej im. Stanisława Staszica w Szczecinie.

3 S. Siadkowski, op. cit., s. 209. 
Po latach przerwy, nawiązując do tradycji spotkań czwartkowych, z inicjatywy Zarządu Okręgu SBP, Koło SBP nr 1 w Książnicy Pomorskiej wraz z Działem Regionalnym Książnicy Pomorskiej zainaugurowało 11 maja 2016 roku cykl spotkań pod wspólnym tytułem: „Środy bibliotekarskie”. Zgodnie z założeniem mają mieć one charakter międzypokoleniowy i dokumentować pamięć o pracy biblioteki i ludzi, którzy ją tworzyli. Każde spotkanie z założenia będzie miało swego bohatera lub temat przewodni. Pierwsze (11.05.2016) poświęcone zostało dr. Stanisławowi Badoniowi (1926-1997), który był pierwszym dyrektorem (1955-1974) Wojewódzkiej i Miejskiej Biblioteki Publicznej w Szczecinie (obecna nazwa: Książnica Pomorska im. Stanisława Staszica), przewodniczącym Zarządu Okręgu Stowarzyszenia Bibliotekarzy Polskich w latach 1956-1975, przewodniczącym Zarządu Głównego SBP (1969-1972), działającym na rzecz upowszechniania czytelnictwa, ochrony piśmiennictwa polskiego, budowania dobrej marki zachodniopomorskiego bibliotekarstwa oraz rozwoju Pomorza Zachodniego.

Bohaterką drugiej środy (14.09.2016) była Krystyna Łyczywek (ur. 1910), uczestniczka powstania warszawskiego, założycielka wypożyczalni książek „Logos”, jednej z pierwszych w polskim Szczecinie. Pani Krystyna, mimo sędziwego wieku, przybyła na spotkanie, podczas którego dzieliła się wspomnieniami $\mathrm{z}$ pionierskich lat Szczecina.

W ramach trzeciej środy (14.12.2016) odbyło się spotkanie z Leokadią Zwilnian Grabowską, liczącą ponad 90 lat nestorką szczecińskiego bibliotekarstwa, bibliotekarką Wojewódzkiej i Miejskiej Biblioteki Publicznej w latach 1960-1981, organizatorką m.in. Gabinetu Konstantego Ildefonsa Gałczyńskiego w WiMBP w Szczecinie. Pani Leokadia, przez wiele lat zajmująca się społecznie sprawami bytowymi zatrudnionych w WiMBP pracowników, także na emeryturze (mimo swej niepełnosprawności ruchowej) integruje środowisko seniorów.

Kolejne spotkanie (14.06.2017) nosiło tytuł „Stanisław Krzywicki - od WiMBP do Książnicy Pomorskiej”. Wieloletni dyrektor (najpierw Wojewódzkiej i Miejskiej Biblioteki Publicznej, potem Książnicy Szczecińskiej, a od 3 października 1994 r. - Książnicy Pomorskiej) opowiadał o rozwoju biblioteki, wdrażaniu nowoczesnych technologii, budowaniu prestiżu instytucji i tworzeniu z oddanych pracy bibliotekarzy zespołu. Spotkanie, podobnie jak inne z tego cyklu, stało się spontaniczną i przebiegającą w wesołym nastroju serdeczną rozmową o minionych latach wspólnej pracy.

Piąta środa bibliotekarska (18.10.2017) poświęcona była działalności instrukcyjno-metodycznej w bibliotekach publicznych ziemi szczecińskiej. 
Głównymi koryfeuszami spotkania byli dr Władysław Michnal, wieloletni kierownik Działu Instrukcyjno-Metodycznego, oraz prof. dr hab. Tadeusz Białecki, ongiś instruktor w tymże dziale. Szczególnie interesujące i ważne dokumentacyjnie okazały się fotografie $\mathrm{z}$ lat 60 . XX wieku, autorstwa prof. Białeckiego, które zachowały się w profesorskim archiwum. Były one komentowane i dopełniane wspomnieniami dawnych pracowników Działu: Urszuli Kaźmierskiej, Atomiry Kubisy, Teresy Biedrzyńskiej, Wiesławy Dziechciowskiej. Wspomnieniom przysłuchiwali się pracownicy Książnicy Pomorskiej, w tym obecni instruktorzy Działu Instrukcyjno-Metodycznego.

\section{Współpraca z redakcją Stownika pracowników książki polskiej}

Idea słownika biograficznego prezentującego dorobek bibliotekarzy, bibliofilów, drukarzy, edytorów, księgarzy, ilustratorów książek zrodziła się w latach 40. XX wieku. Pierwszy tom Stownika pracowników ksiązki polskiej pod redakcją Ireny Treichel (1918-1987) ukazał się nakładem Państwowego Wydawnictwa Naukowego w grudniu 1972 roku (na zamknięcie Międzynarodowego Roku Książki). Irena Treichel, uczennica Heleny Radlińskiej, Jana Muszkowskiego i Heleny Więckowskiej, a więc autorytetów polskiego bibliotekoznawstwa, poświęciła słownikowi czterdzieści lat życia, w tym przeszło ćwierć wieku jako redaktor naczelny. Zatrudniona w Bibliotece Uniwersytetu Łódzkiego, kontynuowała dzieło Adama Łysakowskiego, który, będąc dyrektorem Państwowego Instytutu Książki w Łodzi, rozpoczął pracę nad słownikiem. W pracach nad nim uczestniczyli ponadto m.in. Wiesław Mincer, Ksawery Świerkowski, Witold Pawlikowski. Dzięki ich pracy został wydany w 1958 roku Stownik biograficzny pracowników ksiązki polskiej. Zeszyt próbny.

Po publikacji w 1972 roku pierwszego tomu słownika, który objął około 3 tysięcy biogramów, kontynuowano prace nad jego suplementem. Ukazał się on (bez numeracji) w styczniu 1986 roku ponownie pod redakcją Ireny Treichel i ponownie nakładem Państwowego Wydawnictwa Naukowego.

Kolejny tom Słownika pracowników książki polskiej ukazał się jako jego Suplement II w roku 2000 pod redakcją Hanny Tadeusiewicz z udziałem Bogumiła Karkowskiego. I dopiero w tym tomie opublikowany został pierwszy biogram bibliotekarza z Pomorza Zachodniego. Był nim biogram dr. Stanisława 
Badonia, przygotowany przez redakcję słownika ${ }^{4}$. Natomiast w Suplemencie III do słownika ${ }^{5}$ ukazało się już 27 biogramów zasłużonych bibliotekarzy z naszego regionu: Anny Beaty Chodorowskiej-Gorzelniaskiej (autorka biogramu: Cecylia Judek), Ryszarda Dżamana (autorka: Cecylia Judek), Jana Frankowskiego (autorka: Halina Filip), Jolanty Goc (autorka: Mirosława Różycka), Aleksandry Gustołek (autorki: Anna Bąkowska, Urszula Pleskacz), Józefa Hebala (autorka: Cecylia Judek), Jana Karakulskiego (autorka: Cecylia Judek), Stanisławy Karczewskiej (autorki: Cecylia Judek, Anna Nowakowska), Danuty Marii Kelch (autorki: Cecylia Judek, Anna Lewicka), Marii Krogulskiej (autorka: Cecylia Judek), Ryszarda Majorka (autorka: Regina Bogacka), Tadeusza Malinowskiego (autorka: Cecylia Judek), Tadeusza Marksa (autorka: Cecylia Judek), Stanisława Niśkiewicza (autorka: Cecylia Judek), Marii Pileckiej (autorka: Regina Bogacka), Danuty Przemienieckiej (autorka: Regina Bogacka), Jadwigi Rynkiewicz (autorka: Cecylia Judek), Stanisława Siadkowskiego (autorka: Sylwia Wróblewska), Magdaleny Śliwki (autorzy: Cecylia Judek, Stanisław Krzywicki), Stanisława Telegi (autorka: Cecylia Judek), Marii Salomei Wielopolskiej (autorki: Teresa Jasińska, Anna Łozowska, Cecylia Judek), Franciszka Wójcika (autorki: Zofia Pilarz, Cecylia Judek), Jana Zarańskiego (autorka: Cecylia Judek), Jana Zdulecznego (autor: Stanisław Maruszczak), Krystyny Zgrzebnickiej (autorka: Regina Bogacka), Bożeny Zielińskiej (autorka: Cecylia Judek), Heleny Żak (autorka: Cecylia Judek).

W Suplemencie IV Stownika pracowników ksiażki polskiej ${ }^{6}$ opublikowano kolejnych 17 biogramów bibliotekarzy z Pomorza Zachodniego, takich jak: Tadeusz Biernacki (autorka: Cecylia Judek), Anna Chylińska (autorka: Cecylia Judek), Jan Isadzik-Płacewicz (autorka: Cecylia Judek), Bonifacja Jaworska (autorka: Cecylia Judek), Jadwiga Karpowicz (autorka: Zofia Eckert), Janina Kostulska (autorki: Cecylia Judek, Teresa Ludwikowska), Jadwiga Lesiak (autorka: Cecylia Judek), Zofia Lewandowska (autorki: Cecylia Judek, Teresa Ludwikowska), Janina Molska (autorka: Cecylia Judek), Edward Molski (autorka: Cecylia Judek), Nieściór Józef (autor: Stanisław Maruszczak), Urszula Barbara Szajko

4 Słownik pracowników ksiażki polskiej. Suplement II, pod red. H. Tadeusiewicz z udziałem B. Karkowskiego został wydany w serii: Nauka-Dydaktyka-Praktyka w Wydawnictwie SBP, Warszawa 2000, biogram Stanisława Badonia na s. 15-16.

5 Stownik pracowników książki polskiej. Suplement III, pod red. H. Tadeusiewicz został wydany w serii: Nauka-Dydaktyka-Praktyka w Wydawnictwie SBP, Warszawa 2010.

6 Stownik pracowników ksiązki polskiej. Suplement IV, pod red. M. Rzadkowolskiej został wydany w serii Nauka-Dydaktyka-Praktyka w Wydawnictwie SBP, Warszawa 2010. 
(autorzy: Cecylia Judek, Stanisław Maruszczak), Maria Wrzesień (autor: Władysław Michnal), Władysława Zaremba (autorka: Cecylia Judek).

Wypada odnotować, że w niektórych tomach z serii „Bibliotekarze polscy we wspomnieniach współczesnych", wydawanych przez Wydawnictwo SBP, opublikowane zostały obszerne omówienia działalności kilku bibliotekarzy Pomorza Zachodniego. W tomie pt. „Bibliotekarze bibliotek specjalnych” (Warszawa 2007) ukazał się artykuł Marii Doty-Kurzaj „Tadeusz Biernacki (1917-1994) organizator bibliotek kolejowych w okręgu szczecińskim”. W tomie pt. „Organizatorzy, bibliografowie, dydaktycy" (Warszawa 2015) ukazał się artykuł Cecylii Judek pt. „Bonifacja Jaworska (1926-2010)”.

\section{Sympozja Ludzie książki Pomorza Zachodniego (2013-2017)}

Zachodniopomorski Okręg Stowarzyszenia Bibliotekarzy Polskich we współpracy z dyrekcją Książnicy Pomorskiej w Szczecinie organizuje od 2013 roku cykl sympozjów Ludzie książki Pomorza Zachodniego. Cykl jest poświęcony upamiętnieniu osób uczestniczących w wydawaniu, obrocie oraz upowszechnianiu książek i czasopism, osób promujących czytelnictwo i rozwój bibliotek na Pomorzu Zachodnim, związanych z bibliotekarstwem, bibliotekoznawstwem i informatologią. Preferowana tematyka wystąpień to:

- zasłużeni bibliotekarze wszystkich rodzajów bibliotek, ich życie, praca i osiągnięcia,

- organizatorzy działalności wydawniczej w regionie,

- pozainstytucjonalni animatorzy upowszechniania książek i czytelnictwa,

- twórcy i właściciele kolekcji bibliofilskich,

- księgoznawcy i księgarze,

- antykwariusze.

Sympozja odbywają się corocznie w maju podczas trwania kolejnych edycji Ogólnopolskiego Tygodnia Bibliotek. Teksty wygłoszonych referatów i komunikatów publikowane są na łamach kwartalnika „Bibliotekarz Zachodniopomorski”. Podczas pięciu edycji sympozjów w latach 2013-2017 wygłoszono 46 referatów i komunikatów.

Pierwsze sympozjum (14.05.2013) poświęcone było w dużej mierze ludziom tworzącym podwaliny bibliotekarstwa i czytelnictwa w polskim Szczecinie. Zasługi Jerzego Brinkena, założyciela pierwszej prywatnej wypożyczalni książek w polskim Szczecinie, przedstawiła dr Agnieszka Borysowska, natomiast 
o założonej w 1945 roku Wypożyczalni „Logos” Krystyny Łyczywek mówiła Cecylia Judek. Przemysław Garlicki przypomniał działalność Zbiornicy Księgozbiorów Zabezpieczonych w Szczecinie oraz jej kierowniczkę Marię Quirini. Referat poświęcony pracownikom biblioteki Muzeum Narodowego w Szczecinie (w latach 1945-2009) wygłosiła Marta Kurzyńska z Biblioteki Muzeum Narodowego w Szczecinie, a sylwetkę Danuty Marii Hepke-Kelch, zasłużonej kierowniczki Biblioteki Publicznej im. Marii Dąbrowskiej w Choszcznie, zaprezentowała Anna Kościuczuk z tejże biblioteki. Renata Lis z Biblioteki Wydziału Prawa i Administracji Uniwersytetu Szczecińskiego przedstawiła referat Włodzimierz Świderski jako zastużony bibliotekarz. Szczecińskiego antykwariusza Jana Maziakowskiego przypomniał w swym wystąpieniu ks. dr Jan Mazur, wieloletni duszpasterz środowisk twórczych, laureat „Exlibrisu Książnicy Pomorskiej”.

$\mathrm{W}$ programie pierwszego sympozjum w bloku wystąpień poświęconych działalności wydawniczej Barbara Arsoba-Haddaji omówiła działalność wydawniczą i okołowydawniczą prowadzonego przez siebie Wydawnictwa „Barbara” w Szczecinie, Wydawnictwu „Glob” w Szczecinie poświęciła swój referat Jolanta Liskowacka (Książnica Pomorska), a Marta Kostecka (Miejska Biblioteka Publiczna w Szczecinie) omówiła pracę wydawnictwa Triglav, niedawno założonego w Szczecinie przez Igora Górewicza. Podczas drugiej edycji sympozjum (14.05.2014) przedstawiona została działalność Leona Królaka i Spółdzielni Wydawniczej „Polskie Pismo i Książka” (Urszula Wenta z Książnicy Pomorskiej), Oficyny Archiwum Państwowego w Szczecinie „Dokument” (dr Janina Kosman z Archiwum Państwowego w Szczecinie) oraz Wydawnictwa „Kurtiak i Ley" (Aleksandra Panek z Koszalińskiej Biblioteki Publicznej). Kolejny referent Andrzej Puławski (Książnica Stargardzka) przedstawił działalność wydawniczą Towarzystwa Przyjaciół Stargardu. Sylwetkom zasłużonych bibliotekarzy poświęcili swe wystąpienia: Anna Kościuczuk (referat o Zofii Gołofit-Sobackiej), Małgorzata Bartosik (Dr Erwin Ackerknecht), Alicja Łojko (Urszula Barbara Szajko - wspótczesna kobieta renesansu), Cecylia Judek (Maria Salomea Wielopolska - bibliotekarka, pisarka, filmowiec), Krzysztof Szypowski (Bibliotekarze Collegium i Gimnazjum Petera Gröninga w Stargardzie).

Podczas trzeciego sympozjum Ludzie ksiązki Pomorza Zachodniego (14.05.2015) kontynuowano prezentację wydawnictw. Działalność wydawniczą szczecińskiego oddziału Instytutu Pamięci Narodowej (2005-2015) omówił Paweł Knap. Krystyna Wajda zaprezentowała Wydawnictwo „KryWaj” w Koszalinie. Imponującą aktywność szczecińskiego Wydawnictwa Forma przedstawiła 
Jolanta Liskowacka. Przyczynkiem do dyskusji nad dziejami szczecińskiego drukarstwa w wiekach XVI-XVIII było wystąpienie Alicji Łojko pt. Czarna sztuka w rękach kobiet. Sylwetkę Edwarda Szczęsnego - księgarza i kronikarza przedstawiła Aleksandra Skiba z Książnicy Pomorskiej, a kolejnych zasłużonych bibliotekarzy oraz osoby zasłużone dla rozwoju bibliotekarstwa przedstawily: Marta Kurzyńska (Otto Kunkel - animator bibliotek muzealnych Provinz Pommern), Maria Nowicka (Maria Boniecka - redaktorka szczecińskiego tygodnika „Ziemia i Morze”), Justyna Kowalska (Anny Chylińskiej droga ze Lwowa do Szczecina), Anna Kościuczuk, Izabela Szczyż (Teresa Antoniewicz, zastużona bibliotekarka ziemi choszczeńskiej).

Podczas czwartego sympozjum (12.05.2016) sylwetkę Józefa Kijowskiego, pierwszego szczecińskiego antykwariusza, przedstawiła Maria Nowicka. Życie i działalność Mathausa Heinricha Liebeherra, naukowca i bibliofila zaprezentowała Aleksandra Skiba. Aleksandrowi Majorkowi, zasłużonemu dla koszalińskiego bibliotekarstwa, poświęciła swe wystąpienie Anna Kwiatkowska. Halina Filip, autorka monografii Miejskiej Biblioteki Publicznej im. Galla Anonima w Kołobrzegu, odnalazła w bibliotecznych archiwaliach materiały o Helenie Mieczkowskiej (1906-1994), członkini kołobrzeskiego Koła Przyjaciół Biblioteki, aktywnie współpracującej ze środowiskiem osób niewidomych. Środowisku księgarzy poświęcone było wystąpienie Marii Jaremek (Sekcja seniorów przy Kole SBP nr 1 w Szczecinie), która mówiła o szczecińskich księgarzach, pracownikach Państwowego Przedsiębiorstwa „Dom Książki”. Tematyką księgarską zajęła się też Anna Kościuczuk z Choszczna, która przedstawiła aktywność małżeństwa choszczeńskich księgarzy, Marii i Tomasza Mińskich. Jubileusz 60-lecia wydawania „Materiałów Zachodniopomorskich”, rocznika naukowego Muzeum Narodowego w Szczecinie (1956-2016) stał się pretekstem, by przedstawić ludzi w służbie nauki Pomorza Zachodniego, co uczyniła w swym wystąpieniu Marta Kurzyńska. Maria Jarmoszko-Pożdał z Centrum Oświatowo-Kulturalnego w Ińsku przedstawiła bogato udokumentowaną drogę życiową Florii Jamroży, pierwszej bibliotekarki w polskim Ińsku. Działalność bibliotekarską środowiska akademickiego zaprezentowała Cecylia Judek, pokazując pełne wielu pasji życie Sylwii Wróblewskiej, wicedyrektorki Biblioteki Głównej Politechniki Szczecińskiej.

W programie piątej edycji sympozjum Ludzie książki Pomorza Zachodniego (15.05.2017) dominowały dokumentalno-biograficzne omówienia znanych, mniej znanych, czasem zapomnianych bibliotekarzy ziemi szczecińskiej i koszalińskiej. Urszula Wenta przypomniała działalność bibliotekarską, naukową i publicystyczną 
Stanisława Telegi, Cecylia Judek - prace bibliograficzne i aktywność społeczną Ewy Gos, Anna Kościuczuk zaprezentowała sylwetkę Barbary Wojnowskiej, zasłużonej bibliotekarki ziemi choszczeńskiej, Kazimiera Fecak - Teresy Wójcik, nowogardzkiej bibliotekarki z powołania. Doktor Łukasz Trzeciak z Koszalińskiej Biblioteki Publicznej im. Joachima Lelewela, przedstawił postać Marii Pileckiej (1899-1991), niezwykle zasłużonej dla koszalińskiego bibliotekarstwa siostry legendarnego rotmistrza Witolda Pileckiego. Beata Śpiechowicz z Książnicy Stargardzkiej po iście detektywistycznych poszukiwaniach zrekonstruowała biogram Bronisława Konickiego, zasłużonego dyrektora swej biblioteki. W referacie Grzegorza Piskorza z Działu Zbiorów Specjalnych Książnicy Pomorskiej przedstawione zostały bibliotekarskie, literackie i dziennikarskie wątki w życiu zawodowym Ryszarda Dżamana. Nieco odmienny charakter miało wystąpienie Marty Kurzyńskiej, poświęcone działalności kluboksięgarni Małgorzaty Narożnej FIKA w Muzeum Narodowym w Szczecinie i formom jej pracy z najmłodszymi czytelnikami. Z kolei Izabela Strzelecka z Działu Regionalnego Książnicy Pomorskiej przeniosła uczestników w nieco odległą przeszłość, przedstawiając pomorskie akcenty w biografii kartografa, a także bibliofila Heinricha Berghausa.

Zaletą wielu referatów jest dokumentacja życia ich bohaterów, wykorzystująca rodzinne archiwa. Istotny jest fakt, że powstają one podczas wielokrotnych odwiedzin i rozmów z seniorami lub ich rodzinami. Wystąpieniom referentów bardzo często towarzyszą prezentacje multimedialne, bazujące na nieznanych fotografiach i dokumentach wydobytych z rodzinnych szuflad. Proces przygotowania wystąpień staje się więc procesem budowania ciepłych relacji między seniorami a czynnymi zawodowo bibliotekarzami, co stanowi dodatkową wartość omawianego cyklu sympozjów.

\section{Konkurs im. Stanisława Badonia o Nagrodę Marszałka Województwa Zachodniopomorskiego dla „Bibliotekarza Roku Województwa Zachodniopomorskiego"}

Idea zorganizowania konkursu promującego najbardziej aktywnych, kreatywnych bibliotekarzy Pomorza Zachodniego za dokonania w danym roku była jednym z pierwszych moich pomysłów, który zrodził się po wyrażeniu zgody na przyjęcie funkcji przewodniczącej Zarządu Okręgu SBP w 2005 roku. Konkurs miał jednocześnie upowszechniać rzetelną wiedzę o nowoczesnym bibliotekarstwie, programach rozwoju bibliotek, akcjach upowszechniania czytelnictwa, wdrażaniu 
nowych technologii w automatyzację procesów bibliotecznych, codziennej pracy bibliotek, działających w różnych środowiskach i różnych sieciach: publicznych, szkolnych, akademickich. Po kilkuletnich staraniach uzyskano w 2009 roku zgodę Zarządu Województwa Zachodniopomorskiego na obecnie obowiązującą formę i regulamin Konkursu. Z inicjatywy Zarządu Okręgu SBP patronem Konkursu został dr Stanisław Badoń (1926-1997), który w latach 1955-1974 był wybitnym, wizjonerskim dyrektorem Wojewódzkiej i Miejskiej Biblioteki Publicznej w Szczecinie i który, dzięki dokonaniom kierowanej przez siebie biblioteki, zdobył dla WiMBP w Szczecinie przywilej egzemplarza obowiązkowego i status biblioteki naukowej. Wprowadzenie nowatorskich rozwiązań, m.in. wolnego dostępu do zbiorów, pozyskanie wykwalifikowanych kadr, wprowadzenie do struktury biblioteki nowych agend (dział zbiorów specjalnych, pracownia bibliografii), założenie fachowego czasopisma zbudowało dobry wizerunek szczecińskiego bibliotekarstwa. Od 1974 roku aż do emerytury kierował Biblioteką Główną Politechniki Poznańskiej, wprowadzając w niej nowoczesną strukturę oraz komputeryzację prac bibliotecznych. Na patronat uzyskano zgodę jego żony Marii Badoń.

Zgodnie z regulaminem Konkursu im. Stanisława Badonia o Nagrodę Marszałka Województwa Zachodniopomorskiego dla „Bibliotekarza Roku Województwa Zachodniopomorskiego" wnioski konkursowe nadsyłają koła i oddziały SBP, dyrekcje bibliotek, a także organizatorzy bibliotek. Są one analizowane przez Kapitułę Konkursu, która wyłania w tajnym głosowaniu Bibliotekarza Roku oraz przyznaje 4 wyróżnienia. W I edycji Konkursu Bibliotekarzem Roku 2009 naszego województwa została Danuta Baran z Miejskiej Biblioteki Publicznej im. Stefana Żeromskiego w Nowogardzie. Wyróżnienia otrzymali: Anna Lewicka (Miejska Biblioteka Publiczna im. Marii Dąbrowskiej w Choszcznie), Dariusz Kiełtyka (Biblioteka Publiczna w Gryfinie), Danuta Rembowska (Koszalińska Biblioteka Publiczna im. Joachima Lelewela) i Małgorzata Bartosik (Książnica Pomorska im. Stanisława Staszica w Szczecinie).

W II edycji Konkursu tytuł Bibliotekarza Roku 2010 otrzymała Małgorzata Wojtaluk ${ }^{7}$ z Miejskiej Biblioteki Publicznej im. Gala Anonima w Kołobrzegu. Wyróżnienia otrzymały: dr Agnieszka Borysowska (Książnica Pomorska

7 Małgorzata Wojtaluk zmarła nagle w 2016 r. w wieku 46 lat. Podczas 23 lat pracy w bibliotekach większość swoich działań adresowała do dzieci i młodzieży, działała aktywnie w Stowarzyszeniu Bibliotekarzy Polskich. Za zaangażowanie, propagowanie czytelnictwa, organizację wielu spotkań i imprez dla dzieci otrzymała liczne nagrody i odznaczenia, m.in. Srebrną Odznakę Gryfa Zachodniopomorskiego, statuetkę Kołobrzeskiego Mikołajka od dziennikarzy, a także listy gratulacyjne i podziękowania, m.in. za cykl zajęć dla przedszkolaków „Spotkania z literaturą” czy „Bajkowe poranki”. 
im. Stanisława Staszica w Szczecinie), Anna Styrska (Miejsko-Gminna Biblioteka Publiczna w Bobolicach), Anita Cieślak (Miejska Biblioteka Publiczna im. Jana Kochanowskiego w Międzyzdrojach), Jadwiga Wysokińska (Koszalińska Biblioteka Publiczna im. Joachima Lelewela).

W III edycji Konkursu Bibliotekarzem Roku 2011 została Danuta Krajewska z Koszalińskiej Biblioteki Publicznej im. Joachima Lelewela (kierownik Filii nr 11). Wyróżnione zostały: Bożena Pilczuk (Książnica Pomorska im. Stanisława Staszica w Szczecinie), Halina Kluczewska (Miejska Biblioteka Publiczna im. Marii Dąbrowskiej w Choszcznie), Salomea Barwikowska (Biblioteka Publiczna Miasta i Gminy w Trzebiatowie) oraz Edyta Robakowska-Iwaniec (Biblioteka Publiczna Gminy i Miasta w Sianowie).

W IV edycji Konkursu tytuł Bibliotekarza Roku 2012 otrzymała Andżelika Gałecka, dyrektor Miejskiej Biblioteki Publicznej im. Jana Kochanowskiego w Międzyzdrojach. Wyróżnienia otrzymały: Agata Michalska (Książnica Pomorska im. Stanisława Staszica w Szczecinie), Maria Chmielewska (Biblioteka im. Marii Skłodowskiej-Curie w Policach), Anna Burda (Miejska Biblioteka Publiczna im. Z. Załuskiego w Gryficach), Regina Budrewicz (Biblioteka Publiczna w Drawnie).

W V edycji Konkursu Bibliotekarzem Roku 2013 została Anna Lewicka, dyrektor Miejskiej Biblioteki Publicznej im. Marii Dąbrowskiej w Choszcznie. Wyróżnienia otrzymały: Bożena Pilczuk, (Książnica Pomorska), Renata Kasprzak (Biblioteka im. Marii Skłodowskiej-Curie w Policach), dr Janina Kosman (Biblioteka Archiwum Państwowego w Szczecinie), Marta Kostecka (Mediateka Akademii Sztuki w Szczecinie).

W VI edycji Konkursu Bibliotekarzem Roku 2014 została Monika Kwaśniak, kierownik Działu Instrukcyjno-Metodycznego Książnicy Pomorskiej im. Stanisława Staszica w Szczecinie. Wyróżnienia otrzymały: Anna Leszczyńska (Gminna Biblioteka Publiczna w Marianowie), Ewa Zajkowska (Miejska Biblioteka Publiczna im. M. Dąbrowskiej w Choszcznie ), Anna Korosteńska (Książnica Stargardzka).

W VII edycji Konkursu Bibliotekarzem Roku 2015 została Mirosława Różycka, wicedyrektor Biblioteki Głównej Uniwersytetu Szczecińskiego. Wyróżnienia otrzymały: Halina Filip (Miejska Biblioteka Publiczna im. Gala Anonima w Kołobrzegu) i Elżbieta Niechwiadowicz (Miejska i Powiatowa Biblioteka Publiczna w Świdwinie).

W VIII edycji Konkursu tytuł Bibliotekarza Roku 2016 Województwa Zachodniopomorskiego otrzymały ex aequo: Małgorzata Zychowicz, starszy 
kustosz, kierownik Działu Promocji Koszalińskiej Biblioteki Publicznej im. Joachima Lelewela w Koszalinie, oraz dr Agnieszka Borysowska, kustosz dyplomowany, pracownica Sekcji Rękopisów Działu Zbiorów Specjalnych w Książnicy Pomorskiej im. Stanisława Staszica w Szczecinie. Kapituła nominowała też do etapu centralnego VII edycji Ogólnopolskiego Konkursu „Bibliotekarz Roku” Małgorzatę Zychowicz z Koszalińskiej Biblioteki Publicznej im. Joachima Lelewela w Koszalinie. Wyróżnienia otrzymały: Anita Jurewicz, starszy kustosz, dyrektor Miejskiej i Powiatowej Biblioteki Publicznej im. Cypriana Kamila Norwida w Goleniowie, Katarzyna Zwierzewicz, kustosz, pracownica Czytelni Pomorzoznawczej Działu Regionalnego w Książnicy Pomorskiej im. Stanisława Staszica w Szczecinie oraz Celina Pytlik, bibliotekarz (Gminna Biblioteka Publiczna w Brzeżnie filia w Słonowicach).

Corocznie nadesłane wnioski analizuje kapituła, której członkami, zgodnie z regulaminem Konkursu, są: przedstawiciel Zarządu Okręgu SBP (od początku istnienia Konkursu Zarząd Okręgu SBP reprezentowała Cecylia Judek, inicjatorka Konkursu i w latach 2005-2017 przewodnicząca Zarządu Okręgu), przedstawiciel Dyrekcji Książnicy Pomorskiej, reprezentant Zachodniopomorskiego Porozumienia Bibliotek, przedstawiciel Koła SBP Bibliotek Naukowych Szczecina oraz przedstawiciel Wydziału Kultury, Nauki i Dziedzictwa Narodowego Urzędu Marszałkowskiego (od wielu lat do prac w Kapitule delegowana jest pani Angelika Rotkiewicz).

Należy podkreślić, że laureaci okręgowego etapu, począwszy od II edycji, są kandydatami do tytułu Ogólnopolskiego Bibliotekarza Roku (konkurs organizowany przez Zarząd Główny SBP jest o jeden rok młodszy od organizowanego w naszym województwie). Fundatorem Nagrody im. Stanisława Badonia dla Bibliotekarza Województwa Zachodniopomorskiego oraz wyróżnień dla czterech bibliotekarzy jest corocznie Zarząd Województwa Zachodniopomorskiego. Uroczystość wręczenia nagród połączona jest z wojewódzką inauguracją Tygodnia Bibliotek. Warto dodać, że dla uczczenia zasług i dorobku patrona konkursu, dr. Stanisława Badonia, Zarząd Okręgu podjął zabiegi o nadanie jednej z ulic Szczecina imienia Stanisława Badonia. Propozycja ta została włączona do banku nazw, istniejącego przy jednej z komisji Rady Miasta w Szczecinie i czeka na stosowną lokalizację. Imię Stanisława Badonia, zgodnie z decyzją Dyrekcji Książnicy Pomorskiej w Szczecinie, otrzymała jedna z czytelni Działu Regionalnego Książnicy. W uroczystości uświetniającej jubileusz 110 lat działalności szczecińskiej biblioteki publicznej 5 października 2015 roku uczestniczyli przedstawiciele rodziny patrona. 
Spośród wielu kierunków działania Stowarzyszenia Bibliotekarzy Polskich na Pomorzu Zachodnim warto przypomnieć też prowadzoną od wielu lat akcję wprowadzania w obieg czytelniczy używanych książek, przekazywanych w darze przez mieszkańców regionu, po selekcjach prywatnych bibliotek. Jest to rezultat prowadzonej od dawna akcji informacyjnej. Przeczytane, niepotrzebne, zapomniane książki na organizowanych kiermaszach otrzymują kolejną szansę na spotkanie swego kolejnego czytelnika, a bibliotekarze - nadzieję, że wprowadzając w obieg czytelniczy używane książki, ocalą od wycięcia kilka drzew, a przede wszystkim poprawią niskie statystyki czytelnictwa w Polsce.

Kiermasze „Książka za złotówkę”, „Poczęstuj się książką”, „Pociąg do książki, książka do pociągu” (organizowane na dworcach kolejowych), „Promujemy książki na promie" (organizowane w Świnoujściu) i inne stały się częścią każdorocznego programu działalności SBP.

W roku jubileuszu 100-lecia SBP zrodził się nowy pomysł. Inauguracja pozytywistycznej akcji „Poczekalnia/poczytalnia. Czekając, czytajmy!” nastąpiła w trakcie trwania Kongresu Bibliotek Pomorza Zachodniego 21 czerwca 2017 roku. Aby ułatwić potencjalnym czytelnikom kontakt z książką i sprawić, by czytanie stało się jedną ze zwykłych codziennych czynności, z pozyskanych darów tworzone są niewielkie nietypowe czytelnie. Powstają one w przychodniach, salonach fryzjerskich, u kosmetyczki, w urzędach. Wszędzie tam, gdzie przychodzi czekać nieco dłużej. Wtedy można te wolne, a czasem bardzo denerwujące chwile czekania wykorzystać na czytanie, zaś czytaną książkę każdy będzie mógł wziąć i dokończyć jej czytanie w domu. Następnie może ją pożyczyć innym czytelnikom (krewnym, sąsiadom, znajomym), ewentualnie odnieść, niekoniecznie do tej samej poczytalni. W każdej poczekalnianej biblioteczce znajduje się informacja: „Z tej półki proszę wybrać sobie dowolną książkę i zabrać ją do domu. Po przeczytaniu można ją zostawić w kolejnej dowolnej Poczytalni. Nie traćmy czasu: czekając, czytajmy!"». Autorka referatu ma nadzieję, że to hasło stanie się dewizą każdego z nas.

8 Wykaz pierwszych zorganizowanych poczytalni dostępny on-line: https://infoludek.pl/ kultura/trwa-akcja-poczekalnia-poczytalnia-czekajac-czytajmy (dostęp 1.12.2017). 